\title{
Effect of Newly Created Water Reservoirs on Agricultural Landscape Stability
}

\author{
Przemysław Frankowski ${ }^{1}$, Janina Zbierska ${ }^{2}$, \\ Ryszard Staniszewski ${ }^{2 *}$ Dariusz Kayzer $^{2}$ \\ ${ }^{1}$ Afirma Ltd., Wojnowo, Poland \\ ${ }^{2}$ Poznań University of Life Sciences, Poland
}

Received: 19 April 2018

Accepted: 12 July 2018

\begin{abstract}
The paper presents an assessment of the effect of three water reservoirs near the Nienawiszcz village (Western Poland) on the improvement of landscape structure and stability. The reservoirs were reconstructed in the years 1999-2012 in places where ponds and post-glacial lake were present in the past. A number of works were also carried out to organise and enrich the landscape around studied area, which is a part of real estate. The research carried out in the years 2013-2015 included valorisation of the natural environment, determination of the ecological and spatial model of the landscape and assessment of landscape stability according to the criterion of the connection network. Valorisation of the natural environment has shown the dominance of areas with outstanding and high natural values (class I and II). Regenerated water reservoirs and wood plantings increased the number and diversity of landscape islands and the connections between them, which additionally improved the stability of the landscape. Water reservoirs and numerous landscape activities in this area significantly influenced the increase of biological diversity as well as the diversity and functionality of the landscape.
\end{abstract}

Keywords: water reservoir, agricultural landscape, landscape diversity, landscape stability

\section{Introduction}

Studies on landscape management and the role of waters in landscape is becoming a more appreciated and interesting direction of study around the world [1-3 and others]. It is also due to its meaning for issues related to protection of water reserves in rural areas and recognition of dynamics of biological processes in mature and initial water bodies $[4,5]$. Small aquatic ecosystems are an important element protecting

*e-mail: erstan@up.poznan.pl water resources and differentiating the structure of agricultural landscape. They were underestimated and often liquidated in the past, although they constitute a significant part of aquatic ecosystems in agricultural areas and perform various functions in nature [6-13]. The use of ponds located in agricultural landscapes for the retention of drainage water may lead to an increase in the amount of water resources [14]. Small water reservoirs, variable by nature, stimulate ecological richness and are very rich in terms of diversity of flora and fauna [7, 11, 12, 15-17].

Water reservoirs together with their perimeter are important environmental islands and elements of ecological connections in the agricultural landscape 
$[18,19]$. They are sources of drinking water, mud bathing places, hideouts and places of rest and food for many species of mammals [20]. Enrichment of the landscape with elements such as small retention reservoirs, meadows and mid-field trees intensifies the small circulation of water, increases water retention and prevents the spread of pollution [18]. In areas of intensive agricultural activity, it is necessary to improve the functional structure of the landscape and the efficiency of environmental self-cleaning processes.

Landscape studies and planning activities to preserve the structure and enrichment of the landscape are usually carried out in spatial terms for larger areas, e.g. country, region, commune or a protected area [21, 22]. The practical implementation of these activities largely depends on the structure of land ownership, where private property is often an obstacle.

The purpose of our work was to assess the impact of water reservoirs recreated around the village of Nienawiszcz for improving the structure and stability of the landscape.

\section{Materials and Methods}

The area where the reservoirs are located is varied in terms of landscape, i.e., there are large slopes and significant relative heights. Most of the area within the boundaries of the property is currently used as arable lands situated mostly in the northern and eastern part of the site. Small patches of land in the depressions and on the banks are occupied by permanent meadows. There are also small forest patches as well as afforestations and bushy areas. On the west side (outside the property border) there is a large forest complex belonging to Łopuchówko Forestry Management.

The object of studies were water reservoirs built by a private investor near the village of Nienawiszcz in the Wielkopolska region (western Poland), together with the surrounding area within the limits of property ownership. In 1999-2000, two small ponds were rebuilt (pond I in Fig. 2. with an area of 0.293 ha, pond II in Fig. 2. with an area of 0.915 ha) in the watershed dominated by fields with settlements. Reservoir number III (Fig. 2.) was built in 2004-2012, through the peat extraction and subsequent economic use. After exploitation of the peat deposit additional reclamation work was carried out to maintain appropriate shaping of the bottom construction, leveling the banks and slopes and filling with water. As a result of this project, a water reservoir was created with an area of 11 ha with an average depth of $1.64 \mathrm{~m}$ and a maximum of $3.20 \mathrm{~m}$, natural postglacial slopes and very broad and charming shoreline. The construction of this water reservoir was in a sense a reconstruction of the old, natural reservoir of a glacial origin and contribution to the regulation of water relations and restoration of this area.
The investor's activities were extensive and aimed to create a diverse, harmonious and consistent landscape. These activities, in addition to the rebuilding of reservoirs, included: cleaning up the old clay pit pond filled with waste, maintaining farmland in good agricultural condition, preserving the original vegetation, exposing the erratic boulder, restoring the old earth road, filling up part of the drainage ditch located north of reservoir No. II and leveling the ditch draining excess water from this reservoir into reservoir No. III. In 2000, complementary tree plantings were also made in cooperation with the Łopuchówko Forestry Management in row, tuft and in single forms. Planted tree species were mostly larch (Larix decidua Mill.), spruce (Picea abies L.), beech (Fagus sylvatica L.), plum tree (Prunus cerasifera Ehrh.), birch (Betula pendula Roth.), red oak (Quercus rubra L.) and black pine (Pinus nigra Arn.). Native species, apart from red oak and Douglas fir, were selected for planting, some of which were introduced in the vicinity of reservoir No. I due to their decorative qualities. For aesthetic reasons, clusters were planted along reservoir No. II, which allowed for preserving the visibility of the water surface, while the rows would completely cover it.

The research carried out in 2013-2015 included: valorizing the natural environment, determining the ecological and spatial models of the landscape and assessing landscape stability. The valorization was based on field inventory and the sozologic map. Valorization of the natural environment was carried out using the point bonitation method, in a grid of squares with a side of $100 \mathrm{~m}$ (area of $1 \mathrm{ha}$ ) using a modified 1-5 point scale [23]. The individual squares were assigned point values for certain environmental values, such as: natural forests (5 points), water reservoir (5 points), natural trees and bushes density ( 5 points), single trees (1-5 points, depending on number of trees), island (4 points), peninsulas (4 points), planting trees (4 points), meadows (4 points), drainage ditches (3 points), arable land (3 points), unpaved roads (1 point), varying architecture (1-5 points, depending on the density of the contours). The arithmetic mean of the sum of points in each square was assigned to one of the five valorization classes, which allowed us to determine the diversity of the natural values of the area.

Determining the ecological and spatial model of the landscape was based on the patch-corridor-matrix model concept developed by Forman and Gordon [24]. The assessment of landscape stability was made according to the criterion of the connection network, calculating the indicators $\alpha, \beta$ and $\chi$ according to appropriate formulas [25].

Assessing ecosystem stability in the studied area was calculated using criterion of the network of connections, both for aquatic and terrestrial ecosystems: 


$$
\begin{gathered}
\alpha=\frac{E-V+1}{2 * V-5} \\
\beta=\frac{E}{V} \\
\chi=\frac{E}{3(V-2)}
\end{gathered}
$$

...where indicator $\alpha$ defines the ratio between the existing and the maximum number of connections between patches of natural ecosystems (it takes values $0-1$ ); indicator $\beta$ defines the degree of isolation of the ecosystems (it takes values $0-3$ ); indicator $\chi$ defines the ratio between the existing number of ecological corridors and their maximum number for a given number of patches of natural ecosystems (it takes values $0-1$ ); $\mathrm{E}$ is the number of patches; and $\mathrm{V}$ is the number of corridors.

\section{Results and Discussion}

\section{Valorization of the Natural Environment}

Valorization showed that the analyzed lands are dominated by areas classified as class I and II, with outstanding and high natural values (Fig. 1), which include 21 squares (39\% each). Class I, with outstanding natural and landscape values, includes almost the entire area of reservoir No. III and its shoreline, along with peninsulas and coves. Class I also included a strip of natural woodlands cutting into cultivated fields and planted near a clay pit pond and a southeastern part of the property. In these squares there are numerous ecological corridors in the form of forest belts and natural trees and bush densities that are rich in various species. There are also estuaries of two ditches supplying water to reservoir No. III (from reservoir No. II and adjacent forests). This place is an enclave for numerous species of land and aquatic animals. The squares belonging to valorization class I, located along the east bank of reservoir No. III, are characterized additionally by varied terrain with a significant concentration of contours.

Class II includes 21 squares (Fig. 1). It is an area extending from the northwest to the southeastern part of the property, and the middle section at the eastern border. This class also includes the island, located on reservoir No. III, and reservoirs Nos. I, II and IV, along with their nearest surroundings, which constitute numerous ecological corridors. These squares include many species of trees and shrubs, both natural and planted by the owner, which constitute numerous ecological corridors. The terrain architecture is diversified by water reservoirs and significant differences in terrain ordinates. The value of these squares is only decreased by the vicinity of roads and arable fields. Class III includes 12 squares (Fig. 1) with arable fields in the central part of the analyzed area, along its northern border and in the southeastern corner. The fields are enriched with linear plantings of trees, separating them

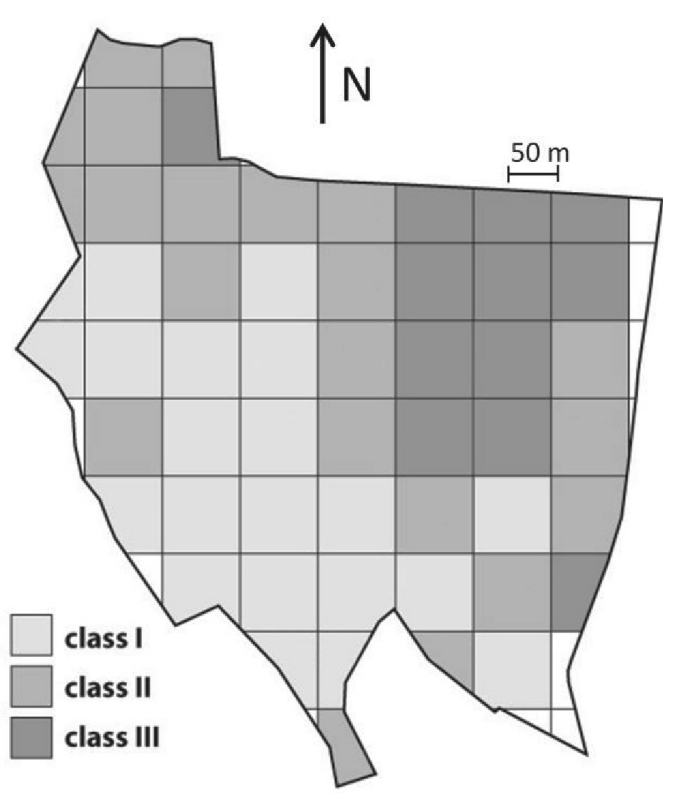

Fig. 1. Valorisation of the area within the boundaries of property ownership.

from roads. The ecological corridors are present there, however, they are poorer in terms of the number and density of species than those in the I and II valorization class.

There are no squares in the analyzed area that could be classified as class IV and V, with small and very small landscape values. This is due to the fact, that the area is very diversified, both in terms of terrain and vegetation. It has as many as three water reservoirs, it is directly adjacent to the forest, arable fields are not degraded, and they are separated from the roads by stripes of planted trees. The meadows, natural woodlands and shrubs as well as drainage ditches are present, and there are no wastelands, buildings, point sources of pollution or degraded elements.

\section{Ecological and Spatial Model of the Landscape}

The layout of matrices, patches and landscape corridors are shown in Figs 2-4. Landscape matrices include forests, arable fields, a gutter and reservoir No. III (Fig. 2). Landscape patches (E) are primarily composed of meadows, water reservoirs, clay pit ponds, tree planting on the banks of water reservoirs and around clay pit ponds and natural midfield tree density (Fig. 3). Forman and Gordon [24] and Solon [26] believe that the smaller the degree of isolation of individual patches, the smaller the risk of extinction of the species that inhabit them. These authors recognize the agricultural landscape as largely fragmented. Possibilities of survival of particular species depend on the nature of the matrices and the size and shape of the patches, the distances between them and the corridors connecting them and the presence of barriers. Corridors 


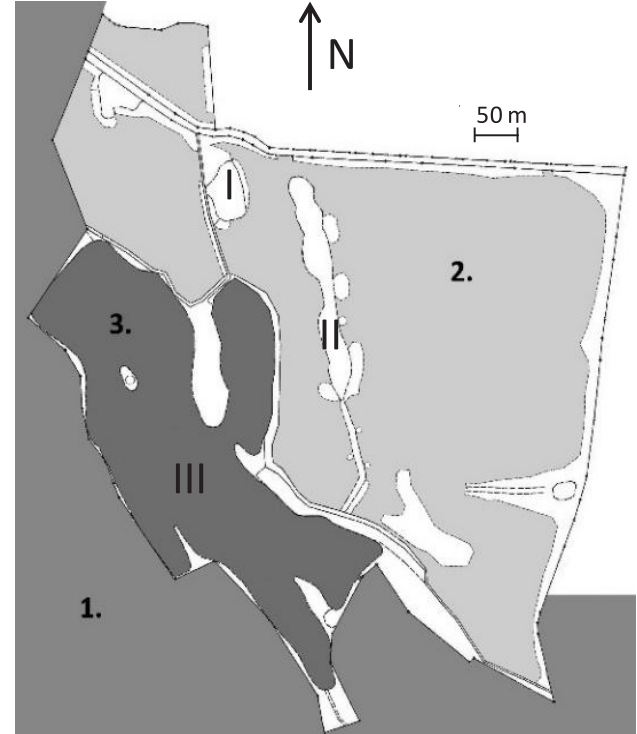

Fig. 2. Landscape matrices. 1 - forests, 2 - arable lands,

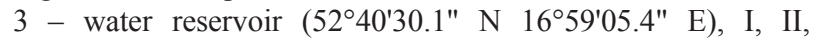
III - studied water reservoirs.

are relatively narrow lanes facilitating the movement of organisms [27]. Landscape corridors (V) in the described area are shown in Fig. 4. They were defined as routes linking the areas with the highest nature value, bypassing the landscape barriers by the shortest route [26]. They include: ditches connecting reservoirs with valleys, ditches supplying water to reservoir No. III, ditch leading from the clay pit pond towards the west, shoreline of reservoir No. II, planting and natural vegetation around reservoirs Nos. I and IV, forest belt along the shore of reservoir No. III, natural trees and

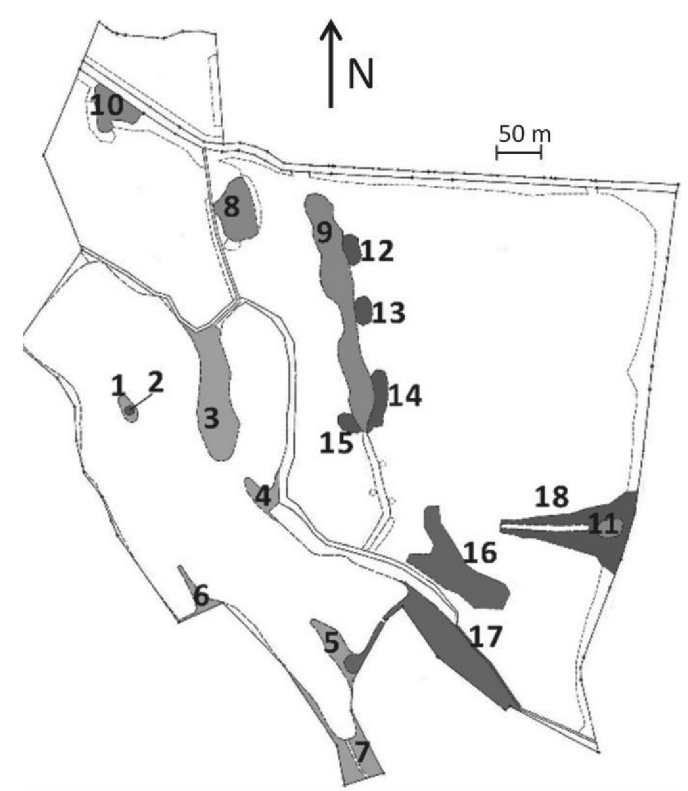

Fig. 3. Patches of landscape (E). 1 - island, 2-7 - meadows, 8-11 - small water reservoirs, $12-15$ and 18 - planted trees, 16-17 - natural field foliage.

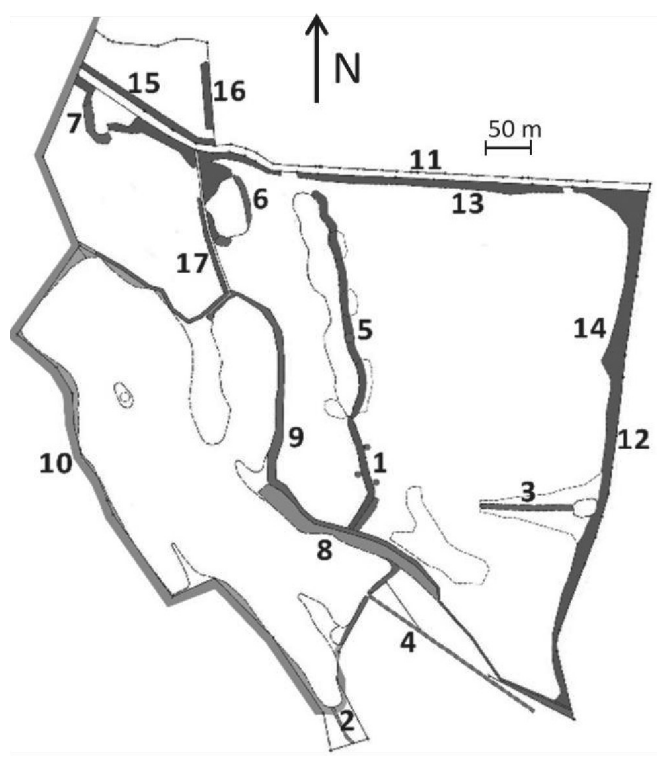

Fig. 4. Landscape corridors (V). 1-4 - ditches, 1-5 - edges of reservoirs, 6 and 7 - vegetation around the reservoirs, 8 and 10 - forest ranges, 9 - natural foliage and bushes, 11-12 - local roads, 13-17 - planted trees.

bushes densities along the bank of the reservoir No. III, forest edge and narrow meadows along the edge of reservoir No. III, local roads, roadside plantings and belt plantings in the field.

The forest is the most suitable food source for animals in the studied area. Reservoir No. III and fields also have high potential, especially during the growing season. The greatest hideout potential is observed in the forest and in midfield tree and bush densities, as well as around reservoirs, and the smallest potential is in the fields. The transport potential is high because there are no clearly marked barriers. Neighboring patches are mostly isolated from each other. It is possible to move freely around reservoir III and along the entire border of the analyzed area, as well as between all three reservoirs. The possibility of migrating species towards the north and northwest is clearly marked.

\section{Evaluating the Stability of Ecosystems}

Assessing ecosystem stability in the studied area, according to the criterion of the network of connections, recognized $14(\mathrm{E})$ and 13 corridors $(\mathrm{V})$ in terrestrial ecosystems and 4 patches (E) and 4 corridors (V) in water ecosystems. Indicators $\alpha, \beta$ and $\chi$ were calculated according to appropriate formulas [25]:

For Terrestrial Ecosystems:

$$
\begin{gathered}
\alpha=\frac{E-V+1}{2 * V-5}=\frac{14-13+1}{2 * 13-5}=0.1 \\
\beta=\frac{E}{V}=\frac{14}{13}=1.08 \\
\chi=\frac{E}{3(V-2)}=\frac{14}{3(13-2)}=0.42
\end{gathered}
$$


For aquatic ecosystems:

$$
\begin{gathered}
\alpha=\frac{\mathrm{E}-\mathrm{V}+1}{2 * \mathrm{~V}-5}=\frac{4-4+1}{2 * 4-5}=0.33 \\
\beta=\frac{\mathrm{E}}{\mathrm{V}}=\frac{4}{4}=1 \\
\chi=\frac{\mathrm{E}}{3(\mathrm{~V}-2)}=\frac{4}{3(4-2)}=0.67
\end{gathered}
$$

The $\alpha$ indicator in relation to the discussed area reached the value of 0.1 for terrestrial ecosystems and 0.33 for aquatic ecosystems. This shows a relatively small number of connections between the patches. On the basis of the $\beta$ indicator, it can be concluded that there is one loop between aquatic ecosystems $(\beta=1)$ and a slightly higher number between terrestrial ecosystems $(\beta=1.08)$. The $\chi$ indicator for this area has reached the value of 0.42 for terrestrial ecosystems and 0.67 for aquatic ecosystems. This means that the corridors here (both aquatic and terrestrial) are of medium length.

Reassuming obtained results, it can be emphasized that valorization of the natural environment within the boundaries of the studied area has shown the domination of areas classified as class I and II, with outstanding and high natural values. There were no areas from IV and V classes, which confirms proper management of the area and the possibility of taking similar solutions in other regions. Rebuilt water reservoirs and simultaneously introduced tree plantings resulted in an increase in the number of landscape islands and connections between them, which contributed to the improvement of landscape stability and diversity. Water bodies with riparian vegetation, landscape islands and linkage among them create a friendly environment for animals visiting this area and even for species (mammals, birds, invertebrates), which could settle inside the studied area [20]. Such islands and links are also important parts of the local environment as a refuge for animals, help in protection of rare species and maintaining contact between isolated populations. According to Forman [28] there are six groups of impacts of ecological corridors on public policy and environment: biological diversity, water resources, agricultural and timber production, recreation and aesthetics, community and cultural cohesion and climate change. In the case of a studied area all of them have its place in this concept. The area has potential for recreation (Nordic skiing, walking, jogging), for specialist tourism as like fishing and other activities for responsible people expecting silence and contact with nature. Recreated water bodies can play a role in maintenance of water level for the surrounding landscape.

Construction of water reservoirs and new afforestations near the village of Nienawiszcz and the numerous landscape activities also improved diversification of the landscape and its functionality. Such a landscape structure can help manage landscape stability, and even the existing corridors are not long. As forests and midfield trees are the best food resource for different animals, the presence of a group of small and medium water bodies increase this potential. Additionally, the possibility of migration of species in different directions is another positive aspect of the studied area.

Taking these into account proved that restoration of water reservoirs in places of their natural occurrence and introduction of trees are the most appropriate and environmentally friendly directions of revitalization and nature restoration activities in the agricultural landscape in lowlands. What is very important in the case of rebuilt water reservoirs, is that the studied area has good groundwater conditions and a stable water table in water bodies, even in years with low precipitation [29]. It should have a positive impact on concentrations of chemical parameters of this basin, especially due to the impact of water level fluctuations on water quality [30-33].

\section{Conclusions}

Results obtained during studies allow us to present the following conclusions:

1. Rebuilt water reservoirs and new tree plantings can increase the number of landscape islands and links between.

2. According to results of undertaken analyses, such a project can improve landscape stability.

3. Construction of water reservoirs and simultaneous afforestation can improve diversification of the landscape and its functionality - even when functioning corridors are short.

4. It is possible to obtain naturally stable water levels in such water bodies if groundwater conditions are favorable.

\section{Conflict of Interest}

The authors declare no conflict of interest.

\section{References}

1. KRAJEWSKI P. Assessing change in a high-value landscape: case study of the municipality of Sobotka, Poland. Pol. J. Environ. Stud. 26 (6), 2603, 2017.

2. YING C., LING H., KAI H. Change and optimization of landscape patterns in a basin based on remote sensing images: a case study in China. Pol. J. Environ. Stud. 26 (5), 2343, 2017.

3. QINDONG F., ZONGZHENG L., LIUKE L., SHENGYAN D., XIAOPING Z. Landscape pattern analysis based on optimal grain size in the core of the Zhengzhou and Kaifeng integration area. Pol. J. Environ. Stud. 27 (3), 1229, 2018. 
4. SZOSZKIEWICZ K., CIECIERSKA H., KOLADA A., SCHNEIDER S.C., SZWABIŃSKA M., RUSZCZYŃSKA J. Parameters structuring macrophyte communities in rivers and lakes - results from a case study in NorthCentral Poland. Knowl. Manag. Aquat. Ecosyst. 415, 8, 2014.

5. PĘCZUŁA W., SZCZUROWSKA A., PONIEWOZIK M. Phytoplankton community in early stages of reservoir development - a case study from newly formed, colored, and episodic lake of mining - subsidence genesis. Pol. J. Environ. Stud. 23 (2), 585, 2014.

6. BIGGS J., NICOLET P., WHITFIELD M., WILLIAMS P. Danger and opportunities in managing temporary ponds. Freshw. Forum. 17, 71, 2001.

7. BIGGS J., WILLIAMS P., WHITFIELD M., NICOLET P., WEATHERBY A. 15 years of ponds assessment in Britain: results and lessons learned from the work of pond conservation. Aquatic Conserv.: Mar. Freshw. Ecosyst. 15, 693, 2005.

8. GAMRAT R. Threat of small midfield ponds on Weltyn Plain. International Agrophysics. 20 (2), 97, 2006.

9. MIODUSZEWSKI W. Small water reservoirs - their function and construction. Journal of Water and Land Development. 17, 45, 2012.

10. NIEDŹWIECKA-FILIPIAK I., SERAFIN L. Function of water in the landscape of the villages in the past and in present, on example of villages in Lower Silesia. J. Ecol. Eng. 16 (1), 92, 2015.

11. WILLIAMS P., WHITFIELD M., BIGGS J., BRAY S., FOX G., NICOLET P., SEAR D. Comparative biodiversity of rivers, streams, ditches and ponds in an agricultural landscape in Southern England. Biol. Cons. 115, 329, 2004.

12. WOOD P.J., GREENWOOD M.T., AGNEW M.D. Pond biodiversity and habitat loss in the UK. Area. 35 (2), 206, 2003.

13. FAIRCHILD G.W., ROBINSON C., BRAINARD A.S., COUTU G.W. Historical changes in the distribution and abundance of constructed ponds in response to changing population density and land use. Landsc. Res. 38 (5), 593, 2013.

14. JUSZCZAK R., KĘDZIORA A., OLEJNIK J. Assessment of Water Retention Capacity of Small Ponds in Wyskoć Agricultural-Forest Catchment in Western Poland. Pol. J. Environ. Stud. 16 (5), 685, 2007.

15. GAMRAT R. Vegetation in small water bodies in the young glacial landscape of West Pomerania. In: Contemporary problems of management and environmental protection, Vol. 2, Wetlands - their function and protection, (Ed.) A. Łachacz, University of Warmia and Mazury, Olsztyn. 95, 2009.

16. JONIAK T., KUCZYŃSKA-KIPPEN N., GĄBKA M. Effect of agricultural landscape characteristics on the hydrobiota structure in small water bodies. Hydrobiologia. 793 (1), 121, 2017.

17. WILLIAMS P., WHITFIELD M., BIGGS J. How can we make new ponds biodiverse? - a case study monitored over 8 years. Hydrobiologia. 597, 1, 2007.
18. HILLBRICHT-ILKOWSKA A. Lake and landscape: ecological links, conclusions for protection. In: Functioning and protection of aquatic ecosystems in protected areas, Eds. B. Zdanowski, M. Kamiński, A. Martyniuk. IRS, Olsztyn. 19, 1999 [In Polish].

19. SYMONIDES E. The role of ecological interactions in the agricultural landscape. Woda Środ. Obsz. Wiej. 10 (4), 249, 2010 [In Polish].

20. BENNET A.F. Linkages in the landscape. The role of corridors and connectivity in wildlife conservation. IUCN, The World Conservation Union, Burwood, Australia, 254, 2003.

21. DAVIES B., BIGGS J., WILLIAMS P., THOMPSON S. Making agricultural landscapes more sustainable for freshwater biodiversity: a case study from southern England. Aquatic Conserv.: Mar. Freshw. Ecosyst. 19, 439, 2009.

22. KISTOWSKI M. The application of landscape ecology conception. PEK. 23, 37, 2009 [In Polish].

23. ILNICKI P. Program of ecological development of Dzierzgoń municipality. Zeszyty Problemowe Postępów Nauk Rolniczych, Poznań, 253, 1996 [In Polish].

24. FORMAN R.T.T., GORDON M. Landscape ecology. New York, J. Wiley and Sons. 619, 1986.

25. RICHLING A., SOLON J. Landscape ecology. Wyd. Nauk. PWN, Warszawa, 464, 2011 [In Polish].

26. SOLON J. The concept of landscape potentials and its application for the landscape connectivity evaluation. PEK. 14, 29, 2004 [In Polish].

27. LIDICKER Jr. W.Z. Responses of mammals to habitat edges: an overview. Landscape Ecol. 14, 333, 1999.

28. FORMAN R.T.T. Landscape corridors: from theoretical foundations to public policy. In: Nature conservation 2: The role of corridors, Eds. D.A. Saunders, R.J. Hobbs. Surrey Beatty \& Sons; Chipping Norton, New South Wales. 71, 1991.

29. FRANKOWSKI P. Environmental, historical and economical value of valley bogs in the Rogoźno commune, Poland. Studia Lednickie. 12, 63, 2013 [In Polish].

30. NÕGES P., NÕGES T., TUVIKENE L., SMAL H., LIGEZA S., KORNIJÓW R., PECZULA W., BECARES E., GARCIA-CRIADO F., ALVAREZ-CARRERA C., FERNANDEZ-ALAEZ C., FERRIOL C., MIRACLE R.M., VICENTE E., ROMO S., VAN DONK E., VAN DE BUND W., NYKANEN M., DE EYTO E., IRVINE K., STEPHEN D., COLLINGS S., MOSS B. Factors controlling hydrochemical and trophic state variables in 86 shallow lakes in Europe. Hydrobiologia. 506-509, 51, 2003.

31. ŁAWNICZAK A.E., ZBIERSKA J., MACHULA S. Effect of shallow lakes on nitrogen form concentrations in river ecosystems. Limnol. Rev. 9 (1), 61, 2009.

32. ŁAWNICZAK A.E., ZBIERSKA J., MACHULA S., CHOIŃSKI A. Fluvial lakes effect on phosphorus and potassium concentrations in the Samica Stęszewska River. Limnol. Rev. 10 (1), 26, 2010.

33. STANISZEWSKI R., SZOSZKIEWICZ J. Changes in the quality of water in Brdowskie Lake in the years in 1997-2006. J. Elem. 15 (4), 705, 2010. 